\title{
Using a Latin Square Design to Determine the Most Effective Mathematics Teaching Method
}

\author{
Charles K. Assuah
}

\begin{abstract}
This study determined the most effective teaching method among four (4) teaching methods (i.e., direct instruction, inquiry-based, cooperative, and guided discovery). The study adopted a 4 x 4 Latin-Square design, using four (4) classes, four (4) teachers and four (4) teaching methods to record students' scores. Participants consisted of forty (40) public high school students and four (4) teachers in a school district in the western region. The results indicated that main effect for teacher was significant, $F(3,15)=37.50, p<0.05, \eta^{2}$ $=0.95$, main effect for class was significant, $F(3,15)=755.83$, $p$ $<0.05, \eta^{2}=0.99$, main effect for teaching method was significant, $\mathbf{F}(3,15)=37.50, p<0.05, \eta^{2}=0.98$. (i.e., there were significant differences in students' scores at all levels with respect to teacher, class, and teaching method). Tukey's HSD post hoc multiple comparison tests indicated that students' scores for direct instruction was significantly lower than their scores for cooperative, $t(6)=-9.50, p<0.05, C . I=[-11.95,-7.05]$, students' scores for direct instruction were significantly lower than their scores for guided-discovery, $\mathrm{t}(6)=-\mathbf{1 5 . 5 0}, \mathrm{p}<0.05$, C. $I=[-17.95,-13.05]$, students' scores for inquiry-based instruction were significantly lower than their scores for cooperative, $\mathrm{t}(6)=-9.50, \mathrm{p}<0.05, \mathrm{C}$. $\mathrm{I}=[-11.95,-7.05]$, students' scores for inquiry-based instruction were significantly lower than their scores for guided-discovery, $t(6)=\mathbf{- 1 5 . 5 0}, p<$ 0.05, C.I $=[-17.95,-13.05]$. Nonetheless, students' scores for direct instruction were not significantly different from their scores for inquiry-based instruction, $\mathrm{t}(6)=.00, \mathrm{p}>0.05$, and students' scores for inquiry-based instruction were not significantly different from their scores for guided-discovery, $t$ (6) $=-15.50, p>0.05$. This study has demonstrated that a Latin-Square design has a greater ability and robustness in detecting treatment differences as compared to a one-way analysis of variance. The study finally concluded that mathematics teachers should be encouraged to use more guided-discovery and cooperative learning methods, in their instructions.
\end{abstract}

Index Terms - Effective teaching methods, instruction, Latin-Square design, multiple comparison tests, main effect.

\section{INTRODUCTION}

In Ghana, mathematics education has recently gained prominence in national debates because it is seen as a catalyst needed to create employment for its younger population. For Ghana to succeed in this endeavor, it will rely on effective mathematics teachers who are conversant with the pedagogy that determines how students learn. These teachers recognize that for students to use mathematics effectively, they need to understand the concept teachers present to them and become fluent with the skills they teach them. Effective mathematics

Charles K. Assuah, Dept. of Mathematics Education, University of Education,Winneba,Winneba,Ghana teachers are not only knowledgeable in the theory of learning mathematics, but they also recognize using concrete materials and visual representations to develop a deep mathematics understanding. They have deep understanding of concepts and employ multiple ways to represent and explain them. They are fluent with the procedures and practices their students need so as to succeed in mathematics. They have a wide array of learning experiences to bring to bear in the classroom to meet the different learning needs of their students. Effective mathematics teachers detect students' misconception sand institute measures to correct them. They encourage their students to take risks during whole class discussions and on individual basis. They encourage their students to use several strategies in a conducive environment which promotes student mathematics learning. The social setting that these teachers provide is equally as important as the physical environment which should occur for good interaction between teachers and students (Hattie, 2003).

\section{LITERATURE REVIEW}

It is evident from a plethora of research that many teachers do not possess the requisite subject-matter knowledge to implement quality instruction (Ball, 1990; Ball \& Bass, 2000; Ball \& Cohen, 1999; Hill, Schilling \& Ball, 2004; Ma, 1999). These teachers do not know in greater depth the mathematical content they teach and are unable to effectively make connections to other important mathematics topics. To improve student mathematics achievement will depend significantly on improving the quality of teaching. Students who receive quality instruction experience greater and more consistent mathematics achievement than their contemporaries who receive poor instruction (Rivkin, Hanushek \& Kain, 2005: Wright, Horn, \& Sanders, 1997). For effective mathematics instruction, teachers should possess a thorough knowledge about the content they teach, they should have knowledge about the mathematics topics students should master to enable them transition into higher order mathematics content, and they should be knowledgeable about the skills and art to teach mathematics effectively (National Advisory Panel, 2008).Teachers who possess strong mathematical knowledge are more likely to encourage students to reason, conjecture, and problem-solve; they are also able to accurately diagnose and address students' mathematical misconceptions and computational fluencies (Kilpatrick, Swafford, \& Findell, 2001).

The relationship between teachers' mathematical knowledge and student achievement has given some credence to the impact of mathematical knowledge on teacher effectiveness (Kilpatrick, Swafford, \& Findell, 2001). As a result, most research on high school mathematics teaching suggests 
general positive influences of teachers' mathematical knowledge on student achievement (Goldhaber \& Brewer, 1997, 2000; Hawkins, Stancavage, \& Dossey, 1998; Monk, 1994; Monk \& King, 1994). It is worthy to comment that enough evidence does suggests that teachers' knowledge of the mathematics content contributes significantly to instructional quality and student achievement (Wilson, Floden, \&Ferrin-Mundy, 2001).Mathematics teachers should be very much concerned about the topics students should master to become proficient in applying the concepts (Kilpatrick, Swafford, \& Findell, 2001). For example, they should teach students to become proficient in whole numbers, fractions, geometry and measurement, since proficiency in these content domains facilitates student understanding and advancement in algebra (NCTM, 2000, 2006). Algebra understanding has long been identified as a prerequisite to students' academic achievement (National Mathematics Advisory Panel, 2008, National Council of Teachers of Mathematics [NCTM], 2001). Students who successfully complete high school algebra are more likely to graduate from high school and university (Rivera-Batiz, 1992).

It is not what mathematics teachers know, but how they know it and what they can mobilize mathematically in the course of teaching (Ball, 2000). This knowledge is explicitly multidimensional (i.e., it comprises of content knowledge, pedagogical content knowledge, and general pedagogical knowledge) (Hill, Ball, \& Schilling, 2008). The notion of a specialized knowledge base for teaching has thoroughly been discussed in the education literature. Shulman (1986) identified a specialized form of teacher knowledge (i.e., pedagogical content knowledge), that is necessary for effective teaching. Shulman defined pedagogical content as the knowledge and means of "representing and formulating the subject that makes it comprehensible to others" (Shulman, 1986, p.9). Shulman argued that content without pedagogy is problematic to the classroom teacher, who relies solely on content knowledge to deliver instruction. Knowledge about how to teach mathematics differs in important ways from the content knowledge possessed by professionals in other mathematics-related disciplines (Hills, Ball, \& Schilling, 2008).

In addition to the pedagogical knowledge espoused by Shulman (1986), effective mathematics teachers should know how students' mathematics knowledge is developed and structured, they should know how to represent mathematical concepts and use them in multiple contexts; they should know how to make students' mathematics understanding visible; and, they should know how to diagnose student misunderstandings and misconceptions and guide them to reconstruct complex conceptual knowledge of mathematics (Ball, Lubienski, \& Mewborn, 2001; Cohen \& Hill, 2000; Darling-Hammond, 1999; Fennema \& Franke, 1992). Mathematics teachers must also understand how students reason and employ strategies for solving mathematical problems (Cobb, 1986).

Aside the foregone discussions, mathematics teachers should also use effective teaching methods in their instructions to enhance students' mathematics achievement. In this study, four teaching methods are discussed and compared: Direct instruction, inquiry-based, cooperative, and guided-discovery method. Direct instruction is a teacher-centered instructional approach that is most effective for teaching basic or isolated skills; it is a systematic step-by-step format that requires student mastery at each step (Kroesbergen \& Van Luit, 2003). Inquiry-based instruction, mainly student-centered and student-directed, allows students to practice problem solving and critical thinking skills themselves to arrive at a conclusion. Guided-discovery instruction values both student exploration and direct teaching. This method provides students with some amount of time to engage in student-centered activities that focus on problem-solving. Teachers take on the role of coaches, using their professional judgment and expertise to decide when it is necessary to provide students with direct instruction and when it is appropriate to give them opportunities for explorations (Kroesbergen \& Van Luit, 2003). The overarching goal of this approach is to foster collaboration and thoughtful interactions with mathematical concepts. In cooperative method, students work together in small groups (i.e., between two to six members in a group). They are usually not grouped by the same ability levels, but they are grouped by a variety of ability levels. Students are given tasks to accomplish under the guidance of their teachers (Kroesbergen \& Van Luit, 2003).

It is worthy to note that, while research on the best mathematics teaching method still remains inconclusive, strong evidence points to the fact that students' conceptual mathematics understanding could be enhanced, if teachers provide them with opportunities to develop their own ideas of the underlying concepts through exploration. However, this is best achieved when teachers provide some reasonable degree of guidance to students (Lazonder \& Harmsen, 2016).In this article, answers to the following research questions were sought for:

(1) Is there any significant difference in students' scores among the four different teachers?

(2)Is there any significant difference in students' scores among the four different classes?

(3) Is there any significant difference in students' scores among the four different teaching methods?

\section{METHOD}

Design

The study adopted a 4 x 4 Latin-Square design for the study. A $4 \times 4$ Latin-Square design is a $4 \times 4$ table filled with different symbols in such a way that each symbol occurs exactly once in each row and exactly once in each column. It is a method of randomly assigning treatments to experimental units so that they appear in a balanced fashion within a square block or field. In this design, there are equal numbers of rows, columns, and treatments. It represents the most popular design when two or more blocking factors are controlled. It is an extreme example of incomplete block design, with any combination of levels involving the blocking factors assigned to one treatment only, rather than to all. Mathematically, the model for the Latin Square design can be represented as:

$y_{i j k}=\mu+\rho_{i}+\delta_{j}+\alpha_{k}+e_{i j k}$, where $y_{i j k}$ is the observation for the experimental unit in the $i$ th row block level, $j$ th column block level and the $k$ th treatment, $i=1,2,3, \& 4 j=1,2,3, \& 4 k=1,2,3, \& 4$. Participants 
The participants consisted of forty (40) junior high school students (20 males and 20 females), and 4 mathematics teachers ( 2 males and 2 females), who were randomly selected from a school district in the western region of Ghana. The ages of the students ranged between 13 and 15 years, while those of the teachers ranged between 28 and 30 . Procedure

Table 1: 4 x 4 Latin-Square for all Factors and Observations

\begin{tabular}{llllll}
\hline & \multicolumn{5}{c}{ Teacher } \\
\hline \multirow{4}{*}{ Class } & & 1 & 2 & 3 & 4 \\
\cline { 2 - 6 } & 1 & $\mathrm{~A}(39)$ & $\mathrm{B}(41)$ & $\mathrm{C}(53)$ & $\mathrm{D}(61)$ \\
& 2 & $\mathrm{~B}(46)$ & $\mathrm{D}(63)$ & $\mathrm{A}(52)$ & $\mathrm{C}(64)$ \\
& 3 & $\mathrm{C}(61)$ & $\mathrm{A}(54)$ & $\mathrm{D}(72)$ & $\mathrm{B}(59)$ \\
& 4 & $\mathrm{D}(88)$ & $\mathrm{C}(82)$ & $\mathrm{B}(76)$ & $\mathrm{A}(77)$ \\
\hline
\end{tabular}

Table 1 indicates a 4 x 4 Latin Square, with teacher and class acting as blocking factors. The teaching methods (direct instruction, inquiry-based, cooperative, guided-discovery) were randomly assigned to each of the sixteen (16) experimental units, while at the same time satisfying the condition for the formation of a Latin Square (i.e., each teaching method appears once in each row and once in each column). All the 40 students were randomly put into each of the 16 experimental units to experience the teaching method and class environment in that unit. A mathematics task was assigned to all the teachers to teach in the respective experimental units. The task was as follows: A pair of fair dice was thrown. If the two numbers that appeared were different, find the probability $p$ that (i) the sum is 6 (ii) an ace appears (iii) the sum is 4 or less. The average marks out of hundred (100) for all the students were recorded in brackets as shown in Table 1.

\section{RESULTS}

Table 2:One-Way ANOVA Table for Teaching Method

\begin{tabular}{lrrrrr}
\hline $\begin{array}{l}\text { Source of } \\
\text { variation }\end{array}$ & SS & DF & MS & F & Sig \\
\hline Between & 697.00 & 3 & 232.33 & 1.17 & 0.36 \\
Within & 2386.00 & 12 & 198.83 & & \\
\hline Total & 3083.00 & 15 & & & \\
\hline
\end{tabular}

A one-way Analysis of variance was conducted to determine if there were differences among the four teaching methods (see Table 2). The results indicated a no significant difference among the four teaching methods, $F(3,12)=1.17, p>0.05$. The Levene's test for equality of variances indicated equal variances among the four teaching methods, $F(3,12)=0.17$, $p>0.05$ (see Table 2).

Table 3: ANOVA Table for a 4 x 4 Latin-Square Design

\begin{tabular}{lrrrrrr}
\hline $\begin{array}{l}\text { Source of } \\
\text { variation }\end{array}$ & $\begin{array}{r}\text { Sum of } \\
\text { Squares }\end{array}$ & $\begin{array}{r}\text { Degrees } \\
\text { of } \\
\text { freedom }\end{array}$ & $\begin{array}{r}\text { Mean } \\
\text { square }\end{array}$ & F & Sig & $\begin{array}{r}\text { Partial } \\
\text { Eta } \\
\text { Squared }\end{array}$ \\
\hline Teacher & 112.50 & 3 & 37.50 & 37.50 & .00 & .95 \\
Class & 2267.50 & 3 & 755.83 & 755.83 & .00 & .99 \\
Teaching & 697.00 & 3 & 232.33 & 232.33 & .00 & .98 \\
Method & & & & & & \\
Error & 6.00 & 6 & 1.00 & & & \\
\hline Total & 3083.00 & 15 & & & &
\end{tabular}

A 4 x 4 Latin -Square design was conducted (see Table 3), to determine if main effects for teacher, class and teaching method were significant (i.e., if significant differences exist in students' scores among all levels of teacher variable, class variable, and teaching method variable). The results indicated a significant main effect for teacher, $F(3,15)=37.50, p<$ $0.05, \eta^{2}=0.95$, significant main effect for class, $F(3,15)$ $=755.83, p<0.05, \eta^{2}=0.99$, and a significant main effect for teaching method, $F(3,15)=37.50, p<0.05, \eta^{2}=0.98$ (see Table 3)

Table 4: Post Hoc Multiple Comparison Test for Teacher

\begin{tabular}{|c|c|c|c|c|c|c|c|}
\hline & \multirow{2}{*}{$\begin{array}{r}\text { (I) } \\
\text { Teacher }\end{array}$} & \multirow{2}{*}{$\begin{array}{r}(\mathrm{J}) \\
\text { Teacher }\end{array}$} & \multirow{2}{*}{$\begin{array}{r}(\mathrm{I}-\mathrm{J}) \\
\text { Mean } \\
\text { Diff } \\
\end{array}$} & \multirow[t]{2}{*}{$\mathrm{SE}$} & \multirow[t]{2}{*}{ Sig. } & \multicolumn{2}{|c|}{$95 \%$ C.I } \\
\hline & & & & & & $\begin{array}{l}\text { Lower } \\
\text { Bound }\end{array}$ & $\begin{array}{l}\text { Upper } \\
\text { Bound }\end{array}$ \\
\hline \multirow[t]{12}{*}{ HSD } & $\begin{array}{l}\text { Teacher } \\
1\end{array}$ & $\begin{array}{l}\text { Teacher } \\
2\end{array}$ & -1.50 & .71 & .25 & -3.95 & 0.95 \\
\hline & & $\begin{array}{l}\text { Teacher } \\
3\end{array}$ & -4.75 & .71 & .00 & -7.20 & -2.30 \\
\hline & & $\begin{array}{l}\text { Teacher } \\
4\end{array}$ & -6.75 & .71 & .00 & -9.20 & -4.30 \\
\hline & $\begin{array}{l}\text { Teacher } \\
2\end{array}$ & $\begin{array}{l}\text { Teacher } \\
1\end{array}$ & 1.50 & .71 & .25 & -0.95 & 3.95 \\
\hline & & $\begin{array}{l}\text { Teacher } \\
3\end{array}$ & -3.25 & .71 & .02 & -5.70 & -0.80 \\
\hline & & $\begin{array}{l}\text { Teacher } \\
4\end{array}$ & -5.25 & .71 & .00 & -7.70 & -2.80 \\
\hline & Teacher & $\begin{array}{l}\text { Teacher } \\
1\end{array}$ & 4.75 & .71 & .00 & 2.30 & 7.20 \\
\hline & & $\begin{array}{l}\text { Teacher } \\
2\end{array}$ & 3.25 & .71 & .02 & 0.80 & 5.70 \\
\hline & & $\begin{array}{l}\text { Teacher } \\
4\end{array}$ & -2.00 & .71 & .11 & -4.45 & 0.45 \\
\hline & $\begin{array}{l}\text { Teacher } \\
4\end{array}$ & $\begin{array}{l}\text { Teacher } \\
1\end{array}$ & 6.75 & .71 & .00 & 4.30 & 9.20 \\
\hline & & $\begin{array}{l}\text { Teacher } \\
2\end{array}$ & 5.25 & .71 & .00 & 2.80 & 7.70 \\
\hline & & $\begin{array}{l}\text { Teacher } \\
3\end{array}$ & 2.00 & .71 & .11 & -0.45 & 4.45 \\
\hline
\end{tabular}

Tukey's HSD post hoc multiple comparison test indicated that students' scores for teacher 1 were significantly lower than their scores for teacher $3, t(6)=-4.75, p<0.05, C$. $I=$ $[-7.20,-2.30]$, students' scores for teacher 1 were significantly lower than their scores for teacher $4, t(6)=$ $-6.75, p<0.05$, C.I $=[-9.20,-4.30]$, students' scores for teacher 2 were significantly lower than their scores for teacher $3, t(6)=-3.15, p<0.05, C . I=[-5.70,-0.80]$, students' scores for teacher 2 were significantly different from their scores for teacher $4, t(6)=-5.25, p<0.05, C . I=[-7.70$, $-2.80]$. Nonetheless, students' scores for teacher 3 were not significantly different from their scores for teacher $4, t(6)=$ $-2.00, p>0.05$, while students' scores for teacher 1 were not significantly different from their scores for teacher $2, t(6)=$ $-1.50, p>0.05$ (see Table 4).

Table 5: Post Hoc Multiple Comparison Test for Class

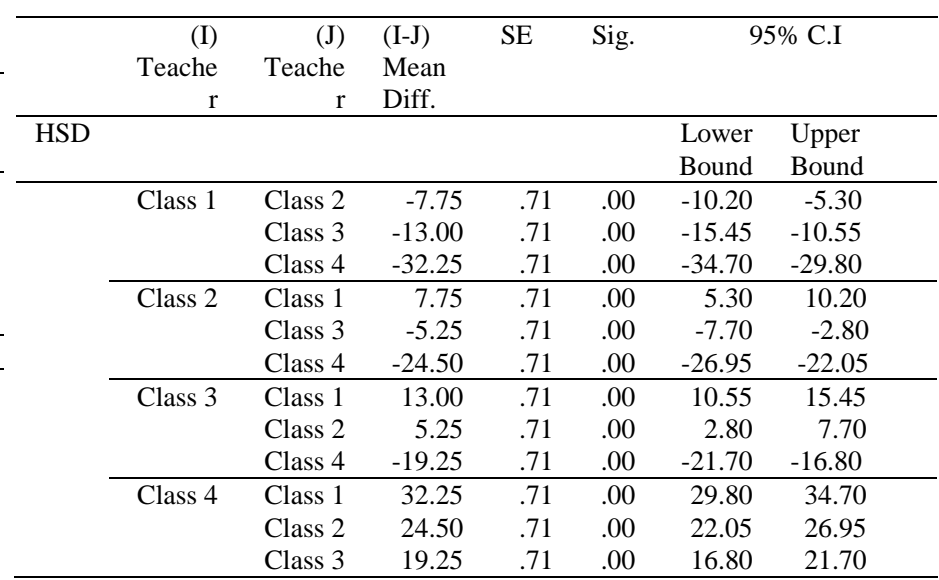


Tukey's HSD post hoc multiple comparison test indicated that students' scores for class 1 were significantly lower than their scores for class $2, t(6)=-7.75, p<0.05, C . I=[-10.20$, -5.30 ], students' scores for class 1 were significantly lower than their scores for class $3, t(6)=-13.00, p<0.05$, C.I $=$ $[-15.45,-10.55]$, students' scores for class 1 were significantly lower than their scores for class $4, t(6)=-32.25$, $p<0.05, C . I=[-34.70,-29.80]$, students' scores for class 2 were significantly lower than their scores for class $3, t$ (6) $=-5.25, p<0.05, C . I=[-7.70,-2.80]$, students' scores for class 2 were significantly lower than their scores for class $4, t$ (6) $=-24.50, p<0.05, C . I=[-26.95,-22.05]$, while students' scores for class 3 were significantly lower than their scores for class $4, t(6)=-19.25, p<0.05$ (see Table 5).

Table 6: Post Hoc Multiple Comparison Test for Teaching Method

\begin{tabular}{|c|c|c|c|c|c|c|c|}
\hline & $\begin{array}{r}\text { (I) Teaching } \\
\text { Method } \\
\end{array}$ & (J) Teaching Method & (I-J) Mean Diff & $\mathrm{SE}$ & Sig. & $95^{c}$ & \\
\hline \multirow{13}{*}{ HSD } & & & & & & Lower Bound & Upper Bound \\
\hline & Direct Instruction & Inquiry & .00 & .71 & 1.00 & -2.45 & 2.45 \\
\hline & & Cooperative & -9.50 & .71 & .00 & -11.95 & -7.05 \\
\hline & & Guided-Discovery & -15.50 & .71 & .00 & -17.95 & -13.05 \\
\hline & Inquiry & Direct Instruction & .00 & .71 & 1.00 & -2.45 & 2.45 \\
\hline & & Cooperative & -9.50 & .71 & .00 & -11.95 & -7.05 \\
\hline & & Guided-Discovery & -15.50 & .71 & .00 & -17.95 & -13.05 \\
\hline & Cooperative & Direct Instruction & 9.50 & .71 & .00 & 7.05 & 11.95 \\
\hline & & Inquiry & 9.50 & .71 & .01 & 7.05 & 11.95 \\
\hline & & Guided-Discovery & -6.00 & .71 & .00 & -8.45 & -3.55 \\
\hline & $\begin{array}{r}\text { Guided- } \\
\text { Discovery }\end{array}$ & Direct Instruction & 15.50 & .71 & .00 & 13.05 & 17.95 \\
\hline & & Inquiry & 15.50 & .71 & .00 & 13.05 & 17.95 \\
\hline & & Cooperative & 6.00 & .71 & .00 & 3.55 & 8.45 \\
\hline
\end{tabular}

Tukey's HSD post hoc multiple comparison tests (see Table 6 ) indicated that students' scores for direct instruction were significantly lower than their scores for cooperative, $t$ (6) $=-9.50, \quad p<0.05, C . I=[-11.95,-7.05]$, students' scores for direct instruction were significantly lower than their scores for guided- discovery, $t(6)=-15.50, p<0.05, C . I=[-17.95$, -13.05], students' scores for inquiry-based instruction were significantly lower than their scores for cooperative, $t(6)=-9.50, p<0.05, C . I=[-11.95,-7.05]$, students' scores for inquiry-based instruction were significantly lower than their scores for guided-discovery, $t(6)=-15.50, p<0.05$, C.I $=$ $[-17.95,-13.05]$. Nonetheless, students' scores for direct instruction were not significantly different from their scores for inquiry-based instruction, $t(6)=.00, p>0.05$, while students' scores for inquiry-based instruction were not significantly different from their scores for guided-discovery, $t(6)=-15.50, p>0.05$.

Table 7: Estimated Marginal Means for Teacher, Class and Teaching Method

\begin{tabular}{|c|c|c|c|c|}
\hline \multirow[b]{2}{*}{ Teacher } & \multirow[b]{2}{*}{ Mean } & \multirow[b]{2}{*}{ SE } & \multicolumn{2}{|c|}{95 C.I } \\
\hline & & & $\begin{array}{l}\text { Lower } \\
\text { Bound }\end{array}$ & $\begin{array}{l}\text { Upper } \\
\text { Bound }\end{array}$ \\
\hline Teacher 1 & 58.50 & 0.50 & 57.28 & 59.72 \\
\hline Teacher 2 & 60.00 & 0.50 & 58.78 & 61.22 \\
\hline Teacher 3 & 63.25 & 0.50 & 62.03 & 64.47 \\
\hline Teacher 4 & 65.25 & 0.50 & 64.03 & 66.47 \\
\hline \multirow{3}{*}{ Class } & \multirow{3}{*}{ Mean } & \multirow{3}{*}{ Std. Error } & \multicolumn{2}{|c|}{95 C.I } \\
\hline & & & Lower & Upper \\
\hline & & & Bound & Bound \\
\hline Class 1 & 48.50 & 0.50 & 47.28 & 49.72 \\
\hline Class 2 & 56.25 & 0.50 & 55.03 & 57.47 \\
\hline Class 3 & 61.50 & 0.50 & 60.28 & 62.72 \\
\hline \multirow[t]{2}{*}{ Class 4} & 80.75 & 0.50 & 79.53 & 81.97 \\
\hline & & & \multicolumn{2}{|c|}{95 C.I } \\
\hline Teaching & Mean & Std. Error & Lower & Upper \\
\hline Method & & & Bound & Bound \\
\hline $\begin{array}{l}\text { Direct } \\
\text { Instruction }\end{array}$ & 55.50 & 0.50 & 54.27 & 56.72 \\
\hline Inquiry & 55.53 & 0.50 & 54.28 & 56.72 \\
\hline Cooperative & 65.00 & 0.50 & 63.78 & 66.22 \\
\hline $\begin{array}{l}\text { Guided } \\
\text { Discovery }\end{array}$ & 71.00 & 0.50 & 69.78 & 72.22 \\
\hline
\end{tabular}

Table 7 indicates the estimated marginal means of two blocking factors (teacher and class), and a treatment variable (teaching method). The estimated marginal mean for teacher was highest for teacher $4, M=65.25$ with $C . I=[64.53$, 66.97], and lowest for teacher $1, M=58.50$ with $C . I=[57.28$, 59.72]. The estimated marginal mean for class was highest for class $4, M=80.75$ with $C . I=[79.53,81.97]$, and lowest for class $1, M=48.50$ with C.I= $[47.28,49.72]$. The estimated marginal mean for teaching method was highest for guided-discovery, $M=71.00$ with $C . I=[69.78,72.22]$, and lowest for direct instruction, $M=55.50$ with $C . I=[54.27$, 56.72].

\section{DISCUSSIONS}

Results of the one-way analysis of variance indicated a no significant difference among the four teaching methods, after meeting the equal variance assumption test. It is worthy to mention that the ability of the Latin-square design to detect differences among the teaching methods could strongly be attributable to the introduction of the two blocking variables, teacher at the column, and class at the row, thereby helping to increase the statistical power of the design. This may have resulted in significant main effects for teacher, class and teaching method (i.e., significant differences in students' scores for all variables: teacher, class, and teaching method). The results also indicated that students' scores for direct instruction were significantly lower than their scores for cooperative and guided-discovery; students' scores for inquiry-based teaching were significantly lower than their scores for cooperative and guided-discovery. However, students' scores for direct instruction were not significantly different from their scores for inquiry-based learning, and also students' scores for inquiry-based learning were not significantly different from their scores for guided discovery. It could be argued that the estimated marginal mean was highest for guided-discovery and lowest for direct instruction because guided-discovery incorporates a balance between direct instruction and inquiry-based learning, while at the 
same time maintaining high levels of cognitive thinking and learning. It also encourages critical thinking, problem-solving, and collaboration and encourages students to work at their own pace by demonstrating their learning in different ways (Kroesbergen \& Van Luit, 2003).

Further, the results indicated that students' scores for teacher 1 were significantly lower than their scores for teacher 3 and teacher 4 , students' scores for teacher 2 were significantly lower than their scores for teacher 3 and teacher 4,and students' scores for teacher 3 were significantly lower than their scores for teacher 4. However, students' scores for teacher 1 were not significantly different from their scores for teacher 2.The estimated marginal mean for teacher is highest for teacher 4 and lowest for teacher 1 because, teacher 4 may have demonstrated a unique and exemplary teaching strategy that enabled the students to record appreciable levels in their scores as compared to teacher 1(Wilson, Floden, \& Ferrin-Mundy, 2001).

Similarly, the results indicated that students' scores for class 1 were significantly lower than their scores for class 2, class 3 and class 4.Students' scores for class 2 were significantly lower than their scores for class 3 and class 4 , while students' scores for class 3 were significantly lower than their scores for class 4 .The estimated marginal mean for class is highest for class 4 , and lowest for teacher 1 because, the classroom environment as well as the seating arrangement may have contributed to the students' scores as compared to class 1 (O’Conner \& Michaels, 1996).

\section{IMPLICATION FOR TEACHING AND LEARNING}

In their rightful order, teachers could resort to the following teaching methods to enhance their teaching: Guided-discovery, cooperative, inquiry-based instruction, and direct instruction. It is worthy to note that, while research on the best mathematics teaching method still remains inconclusive, strong evidence points to the fact that students' conceptual mathematics understanding could be enhanced, if teachers provide them with opportunities to develop their own ideas of the underlying concepts through exploration, but this is best achieved when teachers provide some reasonable degree of guidance to students (Marshal \& Horton, 2011; Lazonder \& Harmsen, 2016).

\section{CONCLUSION}

There were significant differences in students' scores among the four different teachers. Thus, students' scores for teacher 1 were significantly lower than their scores for teacher 3 and teacher 4 ,students' scores for teacher 2 were significantly lower than their scores for teacher 3 and teacher 4, and students' scores for teacher 3 were significantly lower than their scores for teacher 4. However, students' scores for teacher 1 were not significantly different from their scores for teacher 2. There were significant differences in students' scores among the four different classes. Students' scores for class 1 were significantly lower than their scores for class 2 , class 3 and class 4 . Thus, Students' scores for class 2 were significantly lower than their scores for class 3 and class 4 , while students' scores for class 3 were significantly lower than their scores for class 4.There were also significant differences in students' scores among the four different teaching methods. Thus, students' scores for direct instruction were significantly lower than their scores for cooperative and guided-discovery, and students' scores for inquiry-based teaching were significantly lower than their scores for cooperative and guided-discovery. However, students' scores for direct instruction were not significantly different from their scores for inquiry-based learning, and also students' scores for inquiry-based learning were not significantly different from their scores for guided discovery.

\section{References}

[1] Ball, D. L. (1990). The mathematical understandings that prospective teachers bring to teacher education. Elementary School Journal, 90(4), 449-466.

[2] Ball, D. L., \& Bass, H. (2000). Interweaving content and pedagogy in teaching and learning to teach: Knowing and using mathematics. In J. Boaler (Ed.), Multiple perspectives on the teaching and learning of mathematics (pp. 83-104). Westport, CT: Ablex.

[3] Ball, D. L., \& Cohen, D. K. (1999). Developing practice, developing practitioners: Toward a practice-based theory of professional education. In L. Darling-Hammond \& G. Sykes (Eds.), Teaching as the learning profession: Handbook of policy and practice (pp. 3-32). SanFrancisco: Jossey-Bass.

[4] Ball, D. L., Lubienski, S. T., \& Mewborn, D. S. (2001). Research on teaching mathematics: The unsolved problem of teachers' mathematical knowledge. In V. Richardson (Ed.), Handbook of research on teaching (4th ed., pp. 433-456). New York: Macmillan.

[5] Cobb, P. (1986). Contexts, goals, beliefs, and learning mathematics. For the Learning of Mathematics, 6(2), 2-9.

[6] Cohen, D. L., \& Hill, H. C. (2000). Instructional policy and classroom performance: The mathematics reform in California. Teachers College Record, 102(2), 294-343.

[7] Darling-Hammond, L. (1999). Teacher quality and student achievement: A review of state policy evidence. Seattle: University of Washington, Center for the Study of Teaching and Policy.

[8] Fennema, E., \& Franke, M. L. (1992). Teachers' knowledge and its impact. In D. A. Grouws (Ed.), Handbook of research on mathematics teaching and learning (pp. 147-164). New York: Macmillan.

[9] Goldhaber, D. D., \& Brewer, D. J. (1997). Why don't schools and teachers seem to matter? Assessing the impact of unobservable on educational productivity. Journal of Human Resources, 32(3), 505-523.

[10] Goldhaber, D. D., \& Brewer, D. J. (2000). Does teacher certification matter? High school teacher certification status and student achievement. Educational Evaluation and Policy Analysis, 22(2), 129-145.

[11] Hattie, J. (2003). Teachers make a difference. What is the research evidence? Paper presented at the Australian Council for Educational Research Annual Conference on Building Teacher Quality, Melbourne.

[12] Hawkins, E. F., Stancavage, F. B., \& Dossey, J. A. (1998). School policies and practices affecting instruction in mathematics: Findings from the National Assessment of Educational Progress (NCES No. 98-495). Washington, DC: U.S. Department of Education, Office of Educational Research and Improvement.

[13] Hill, H. C., Ball, D. L., \& Schilling, S. G. (2008). Unpacking pedagogical content knowledge: Conceptualizing and measuring teachers' topic-specific knowledge of students. Journal for Research in Mathematics Education, 39(4), 372-400.

[14] Hill, H. C., Schilling, S. G., \& Ball, D. L. (2004). Developing measures of teachers' mathematics knowledge for teaching. Elementary School Journal, 105(1), 11-30.

[15] Kilpatrick, J., Swafford, J., \& Findell, B. (Eds.). (2001). Adding it up: Helping children learn mathematics. Washington, DC: National Academies Press.

[16] Kroesbergen, E.H., and Van Luit, J.E., (2003). Mathematics Interventions for Children with Special Educational Needs, a Meta-Analysis. Remedial and Special Education, 24(2), 97-114

[17] Lazonder, W., \& Harmsen, R. (2016). Meta-Analysis of Inquiry-Based Learning: Effects of Guidance. Review of educational Research, 86(3), 681-718.

[18] Ma, L. (1999). Knowing and teaching elementary mathematics: Teachers' understanding of fundamental mathematics in China and the United States. Mahwah, NJ: Lawrence Erlbaum Associates.

[19] Monk, D. H. (1994). Subject area preparation of secondary mathematics and science teachers and student achievement. Economics of Education Review, 13(2), 125-145. 
[20] Monk, D. H., \& King, J. A. (1994). Multilevel teacher resource effects on pupil performance in secondary mathematics and science: The case of teacher subject-matter preparation. In R. G. Ehrenberg (Ed.),

Choices and consequences: Contemporary policy issues in education (pp. 29-58). Ithaca, NY: ILR Press.

[21] National Mathematics Advisory Panel. (2008). Foundations for success: The final report of the National Mathematics Advisory Panel. Washington, DC: U.S. Department of Education. Retrieved July 03 , 2019, from http://www.ed.gov/about/bdscomm/list/mathpanel/ report/final-report.pdf

[22] National Council of Teachers of Mathematics. (2000). Principles and standards for school mathematics. Reston, VA: Author.

[23] National Council of Teachers of Mathematics. (2001). Principles and standards for school mathematics. Reston, VA: Author.

[24] National Council of Teachers of Mathematics. (2006). Curriculum focal points for 'prekindergarten through Grade 8 mathematics: A quest for coherence. Reston, VA: Author.

[25] O'Connor, M.C., \& Michaels, S. (1996). Shifting participant frameworks: Orchestrating thinking practices in group discussion. In D. Hicks (Eds.), Discourse, learning and schooling (pp. 63-103). New York: Cambridge University Press.

[26] Rivera-Batiz, F. L. (1992). Quantitative literacy and the likelihood of employment among young adults in the United States. Journal of Human Resources, 27(2), 313-328.

[27] Rivkin, S.G., Hanushek, E.A., \& Kain, J.F. (2005). Teachers, schools, and academic achievement. Econometrica, 73(2), 417-458.

[28] [28]Shulman, L. S. (1986). Those who understand: Knowledge growth in teaching. Educational Researcher, 15(2), 4-14.

[29] Wilson S. M., Floden, R. E., \& Ferrini-Mundy, J. (2001). Teacher preparation research: Current knowledge, gaps, and recommendations (Research Report No. R-01-3). Seattle, WA: Center for the Study of Teaching and Policy. Retrieved July 05, 2019, from http://depts.washington.edu/ctpmail/PDFs/TeacherPrep-WFFM-02-2 $\underline{00}$ 1.pdf

[30] Wright, S.P., Horn, S.P., \& Sanders, W.L. (1997). Teacher and classroom context effects on achievement: Implications for teacher evaluation. Journal of Personnel Evaluation in Education, 11, 57-67.

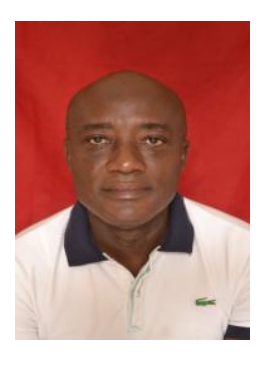

Charles K. Assuah has $\mathrm{PhD}$ in Curriculum, Teaching and Learning with emphasis in Mathematics Education from University of Nevada, Reno, U.S.A. He also has MSc (Mathematics) degree from Youngstown state university in Oh, U.S.A, and BSc (Mathematics) degree from Kwame Nkrumah University of Science \& Technology, Kumasi, Ghana. His career focus and philosophy are as follows: The diverse and rapidly changing global society requires mathematics teachers who possess broad and strong fund of knowledge that will enable them to teach with understanding in their academic disciplines to impact student learning. Consequently, his career focus is to train mathematics teachers to develop intellectual capacity and curiosity that will position them to anticipate and respond to the diversity of human conditions and problems that impact our educational processes. He also plans to train mathematics teachers to reinvent themselves in relevant and purposeful ways as they engage with others in their educational pursuits. Finally, he plans to train mathematics teachers to become aware of the realities of human relations and the manner in which individuals or groups of diverse background interact within and between groups. To enable him accomplish the above, he values academic excellence and integrity; outstanding teaching and service; effective professional leadership; individual and collective excellence; diversity, equity and social justice; education of individuals across the life span, and collegiality and collaboration. 